from the non-random breakage and exchange of non-sister chromatids but that this exchange process involves localised past-zygotene DNA-synthesis at the break points. During this repair synthesis allelic recombination may take place in conjunction with the non-allelic. Whitehouse claims there are several points of agreement between his postulated mechanism for crossingover and the requirements of Revell's chromatid exchange hypothesis. What these points are is not discussed. Indeed when one examines this claim in detail it would appear that there is an internal inconsistency of ideas. The exchange hypothesis, as originally proposed, argued that chromatid breakage produced by irradiation was not a primary but a secondary event. The primary step was the production of an undefined " exchange initiation". This, if subsequently completed, led to an actual exchange and if incomplete gave rise to either a chromatid or an iso-chromatid break. If we regard crossing-over as an exchange process then in terms of Whitehouse's argument breakage precedes exchange whereas in the Revellian scheme breakage is a consequence of incomplete exchange.

Issues like this-and others could be raised-are, of course commonplace to the practising scientist who is familiar with both the exceptional and the accepted. Even for him, however, it is often easier to ignore the exceptional than to attend to it, despite the fact that the pursuit of exceptions often determine the course of science. This book is intended for "Biology students at universities, including research students in the more marginal areas of genetics or in cognate subjects ". One wonders how discerning they will be.

Nevertheless, whether we agree or disagree with Whitehouse's contentions-and time will give us an answer-we must not fail to recognise in his book the intellectual stimulation he has aimed to give to its readers. In this sense this book must succeed. It deserves to be read widely-but wisely!

B. John.

\title{
NEW INSIGHT INTO AN OLD STORY
}

ORIGINS OF MENDELISM. Robert C. Olby. Constable, London, 1966. Pp. 204, 4 tables, 12 plates. 30s.

The blaze of Mendel's contribution to science as the founder of genetics has eclipsed the image and the work of his predecessors in plant hybridisation in the eyes of modern biologists, and Dr Olby has performed a valuable service in bringing Koelreuter, Gärtner, and others out of their darkness, in this admirable book. He shows that Mendel had roots more firmly planted in the work of his predecessors than had been recognised. After all, it was Koelreuter who introduced the practice of experiment into plant breeding; and his contribution to science in establishing the fact of sexuality in plants, in disproving the notion (due to Linnaeus and Buffon) that the father controlled the outermost characters and the mother the innermost in offspring, in disproving the hypothesis of preformation in the germ, and in accomplishing "transmutation" from one species to another, are all deserving of more recognition than they have received.

The use of the term "transmutation" here shows how careful it is necessary to be in studies on the history of science. When Darwin opened his " Notebook on transmutation of species", he was studying the possibility

2 L 2 
that the offspring of an existing species might be modified and eventually give rise to a new and hitherto inexistant species. Yet here was Koelreuter, who believed in the fixity of species, succeeding as a result of crossing Nicotiana rustica with $\mathcal{N}$. paniculata and pollinating the hybrid offspring, generation after generation, from one parental species, in converting the offspring of one known species, $\mathcal{N}$. rustica, into another known species, $\mathcal{N}$. paniculata: transmutation without evolution.

Dr Olby's account of Mendel's life and of his formative years in Vienna is of the greatest interest, and shows the importance of the influence on young Mendel of Franz Unger, the botanist who in 1852 already denied the fixity of species, and particularly of the physicists Doppler and von Ettinghausen to whom Mendel must have owed his mathematical approach to the problem of genetic mechanism, which enabled him to do what nobody had done before and provided the setting for the spark of creative mental activity which he kindled. Remarkable also is the author's well argued case for the view that it was in order to study the problem of evolution that Mendel embarked on his experiments. This reinforces the conclusion, already arrived at by Fisher, that Mendel's paper reflects in many places his answer to Darwin's difficulties as expressed in the Origin of species, which Mendel must have read before he gave his paper.

Sound research in the history of science is capable of a kind of chainreaction in throwing light on cognate problems. It was remarkable to find as the author did, that in a letter to Darwin, Francis Galton suggested the Mendelian system and ratios, and that neither sender nor recipient ever did anything about it. The falseness of the trail which Darwin followed in his unfortunate "provisional hypothesis of pangenesis" shows up all the more clearly in Dr Olby's analysis. He also has an ingenious alternative explanation for Fisher's demonstration that Mendel's ratios were too good to be true for the comparatively small number of individuals tested in his experiment. Fisher suggested that this was the result of over-enthusiastic assistants, who knew what Mendel wanted, giving the experiment " the benefit of the doubt" of difficult specimens. Dr Olby, who finds that the same problem arises with Tschermak's ratios, suggests simply that counting stopped when the expected ratio had been obtained. This startling solution, comparable to a cessation of counting votes at an election when the prediction of the opinion-polls has been realised, itself raises problems both of statistics and of methodology on the part of the experimenters. Another problem which partakes more of a moral nature, revealed by the author, is the equivocal behaviour of de Vries in acknowledging Mendel's priority, and his refusal to subscribe to the monument erected in Mendel's honour. As Dr Olby points out, if it had not been for those 44 pages published in I866, Mendel's Law would be known as de Vries's Law. Hinc illae lacrimae. Wallace might have said the same of Darwin, but he did not. History of science, when written by scientists for scientists, can be not only of fascinating interest but of great importance, as Dr Olby's book is.

Gavin de BeER.

\section{BOOKS RECEIVED}

MOLEKULAR GENETIK. N.P. Dubinin. Gustav Fischer, Jena, 1965. Pp. 168. \&1, 10s. 11d.

SCHOPFUNGSTAG UND MENSCH DER ZUKUNFT. Paul Lüth. Eugen Diederichs, Düsseldorf-Köln, 1966. Pp. 350. DM. 14.80. 